\title{
A kisgyermekkori matematikai kompetenciákról alkotott nézetek változása
}

\author{
KISSNÉ ZSÁMBOKI RÉKA \\ Soproni Egyetem
}

\begin{abstract}
Napjainkban márköztudott tény, hogy a csecsemö és a kisgyermekkor meghatározó jelentöségü a személyiség komplex és harmonikus kibontakoztatása, a korai megismerö folyamatok és szociális tanulás támogatása tekintetében. Varga Tamás a matematikatanitás nemzetközileg elismert hazai kutatója és képviselöje szerint a kisgyermek önmagát épitö, konstruáló személyiség, akinek fejlödéséhez olyan kedvezö feltételeket kell teremteni, amelynek során a mozgás, a játék, a tevékenykedés, a kiváncsiság, a gyermeki érdeklödés alapvetö szerepet kaphat. Ebben a folyamatban gazdag matematikai tapasztalatszerzésre, a numerikus képességek és kompetenciák fejlesztésére is lehetöség nyílik. Jelen tanulmány célja, hogy a gyermeki gondolkodás, számérzék, számdiszkriminációs képesség és a koragyermekkori matematikai kompetenciákról alkotott tudományos elképzelések változásainak tükrében felhivja a figyelmet a kisgyermekkori matematikai nevelés jelentöségére és szükségességére a bölcsődei nevelésen innen és túl.
\end{abstract}

Kulcsszavak: gondolkodási és fogalomalkotási folyamatok, koragyermekkori számérzék, öröklött numerikus képességek, matematikai kompetenciák

\section{Bevezető gondolatok}

„A matematika az emberi elme alkotása, egyszerre az agy és a kultúra evolúciójának a ter-

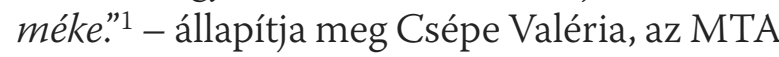
egykori főtitkárhelyettese, az akadémia Agyi Képalkotó Központjának kutatóprofesszora. A kisgyermekkori fejlődés és a matematikatudománya azonban hosszú évszázadokig egymástól nagyon távoli, össze nem egyeztethető fogalmak voltak. Az intelligenciát és a mentális folyamatokat kutató szakterületek kibontakozásával, valamint a kognitív pszichológia megjelenésével - többek között Jean Piaget, Varga Tamás, Pólya György tudományos elméleteinek köszönhetően ma már a születés pillanatától beszélhetünk matematikai felfedezésekről, tapasztalatszerzésről. Varga Tamás matematikatanár, a matematikatanítás nemzetközileg elismert kiemelkedő egyénisége négy évtizeddel ezelőtt, az Élet és Tudomány folyóiratban közzétett Babamatematika" és "Óvodáskorúak matematikája” című írásaiban rámutatott, hogy miközben a

\footnotetext{
${ }^{1}$ http://mipszi.hu/cikk/091212-szamolo-agy
}

kisbaba érzékszerveivel, mozgása, hangadása révén kapcsolatba kerül élő és tárgyi környezetével, tájékozódásának olyan elemei is vannak, amelyeket matematikai jellegünek is mondhatunk. Vélekedése szerint a kisgyermek önmagát építő, konstruáló személyiség, akinek sem a mozgás- sem a beszédfejlődését nem kell siettetni, erőltetni, irányítani, csupán olyan kedvező feltételeket kell teremteni a természetes fejlődés számára, amelynek során a mozgás, a játék, a tevékenykedés, a kíváncsiság, a gyermeki érdeklődés alapvető szerepet kaphat. Ebben a fejlődésmenetben gazdag matematikai tapasztalatszerzésre is lehetőség nyílik. A cselekvésekhez kapcsolódó képi és a nyelvi információknak is fontos matematikai elemei, tartalmai lehetnek (Kissné, 2017). A kisgyermekek fejlődésének tudatos segítéséhez azonban leggyakrabban nem kell bonyolult feladatokat végeztetni, és nem lehet elvont fogalmakat megtanítani. A gyerekek már születésüktől készek arra, hogy tanuljanak, természetüktől fogva kíváncsiak és motiváltak arra, hogy felfedezzék a környező világot. Az őket körülvevő személyeken és ingergazdag környezeten múlik, hogy ezt a természetes kíváncsiságot megőrzik-e 
a későbbiekben. A változatos gyermeki tevékenységek sorában szinte alig találni olyat, amelyben ne lenne jelen valamilyen közvetett vagy közvetlen matematikai tapasztalat, ismeret. Ezeket a külső világ felfedezésének során tapasztalatok és élmények útján észrevétlenül sajátítják el a gyermekek. Így számukra a matematikai megismerés folyamata érdekes és izgalmas felfedezés, amely sikerélmények esetén jó inspiráció a további kísérletezésre.

\section{A kisgyermekkori fejlődés sajátosságairól vallott nézetek változása}

A gyermeki fejlődés tudományos megközelítéséről számos hazai és nemzetközi szakirodalom szól. A biológiai érés koncepciója kimondja, hogy a fejlődésnek van egy genetikailag is meghatározott, a humán természetből adódó sajátossága. Az érés dominanciáját hangsúlyozó elmélettel szemben a tanuláselmélet szerint a gyermeki személyiséget és aktivitást formáló környezetben megfelelő lesz a fejlődés. Szerintük az egyént az élete folyamán a környezete formálja, jutalmazással, büntetéssel. A tanuláselmélet a taníthatóság szempontjából nagyfokú optimizmust tükröz, de egyben azt a rejtett üzenetet is hordozza, hogy ha nem megfelelö a gyermek fejlődése, akkor ezért a környezete lehet a felelős (Pléh, 2010). A 21. századi tanuláselméletek kifejtik, hogy a gyermek számára biztosítanunk kell az ingergazdag materiális környezetet, amely alkalmas az explorációra. Hagynunk kell, hogy a gyermekek önállóan tevékenykedhessenek, amely segíti a tanulásukat. A szociális tanuláselmélet megalkotója (a kanadai származású pszichológus Albert Bandura) szerint a gyermekek tanulásának fontos formája mások viselkedésének, érzelmeinek, attitűdjeinek megfigyelése. Lényeges a gyermek aktív figyelme a szociális tanulás közben. Megfigyelték, hogy a gyermekek nem utánoznak bárkit, csak a számukra fontos, pozitív modelleket. Éppen ezért állandóan törekednünk kell arra, hogy viselkedésünk, gondolkodásunk, kapcsolataink stb. utánzásra késztető jó minták legyenek a gyermekek számára (Pléh, 2010).
A matematikai kompetenciák fejlődése és fejlesztése szempontjából számunkra talán legérdekesebb elméletek a kognitív változásokat hangsúlyozó és a kognitív idegtudomány, illetve a születőben lévő új tudományág a neuropedagógia koncepciója. Jean Piaget, svájci pszichológus saját gyermekeinek megfigyelésével és sok fejlődéslélektani kísérlet alapján dolgozta ki elméletét, mely szerint a gondolkodás a fejlődés előidézője. Az elmélet középpontjában a gyermek világképe áll, az a séma, amit a gyermek állandó gondolkodással konstruktívan épít. Amikor találkozik egy új jelenséggel, akkor beilleszti az eddigi tudásába (asszimiláció), vagy átformálja az eddigi világképét úgy, hogy most már az új jelenség is megmagyarázhatóvá váljon (akkomodáció). Ez a folyamatos adaptáció, azaz tanulás egész életünkön át tart.

A neurológia, a kognitív idegtudomány és a belőle táplálkozó, neveléstudományi alapokon nyugvó neuropedagógia szerint az agy alapvető struktúrája egy hosszantartó fejlődési folyamat során épül fel, amely már a magzati életben elkezdődik. Az agy plaszticitása koragyermekkorban (az első 5-6 évben) a legnagyobb. A specializáltabb agy később egyre nehezebben képes a nagyon új vagy nem várt kihívásokhoz alkalmazkodni (Schiller, 2010). Az utóbbi évtizedek kutatási eredményei azt mutatják, hogy mindannyian egy alapvetően személyi környezetre „programozott" aggyal születünk, és már csecsemőkorban birtokunkban van néhány, az emberi és tárgyi világról szóló alapvető információ. Annak ellenére, hogy a gyermeki agy tömege négyszer kisebb mint a felnőtteké, egy újszülött gyermek elméjében majdnem az összes neuron jelen van, amit majd a későbbi életében használni fog. A növekedést a sejtek közötti nyúlványok bonyolult hálózatának kialakulása segíti elő, melynek kiépüléséhez sok-sok egyéni tapasztalatszerzésre van szükség. Donald Hebb „Fire Together - Wire Together" elmélete szerint az ingerek hatásának következtében az egymáshoz hasonló funkciójú sejtek jelzéseket adnak, és azok felé kezdenek nyúlványokat növeszteni, amelyek saját jeleiket velük egyidőben sugározzák. A 
A kisgyermekkori matematikai kompetenciákról alkotott nézetek változása

fentiek alapján elmondható, hogy a neuronok hálózata nem csupán véletlenszerủ és nem is elöre beprogramozott, hanem a tapasztalat által formálódik. A kialakult szinapszisok közül csak azok maradnak meg tartósan, melyeket rendszeresen használunk, a többit a szinaptikus „visszametszés” révén elveszítjük (Keysers E Gazzola, 2014).

Ezen az alaptudáson kívül velünk születik egy nagyon hatékony tanulási képesség és a tanulásra való alapvető igény. A szociokulturálisan is meghatározott tanulási folyamatban a gyermek nem csupán saját megfigyeléseire, tapasztalataira, hanem az őt körülvevő személyekkel folytatott interakciókra támaszkodik. A gyermekek tanulásában és fejlődésében tehát jelentősen meghatározó az emberi kapcsolatok minősége. Daniel N. Stern, a 20. századi kötődéselmélet egyik jeles képviselője a gyermekek tanulásában meghatározó jelentőségűnek tartja a szociális kapcsolatokat. A gyermeki személyiséget meghatározó tényezők és összetevők mint például a pozitív énkép, a bizalom- és biztonságérzet és akár az önreflexió kialakulása is jelentősen függ a megélt pozitív vagy negatív kapcsolatoktól és élményektől. A gyermekekkel való pozitív, hiteles, közvetlen kapcsolatnak olyan ereje van, amely a gyerekek fejlődését minden területen elősegíti. A koragyermekkor időszakában szerzett tapasztalatok, a családi élet jellemzői és a környezeti (pedagógiai) stimuláció minősége tehát egyértelműen befolyásolja a gyermekek egészséges fejlődését, annak kognitív, érzelmi és szociális megalapozottságát (Stern, 2002).

\section{A matematikai tapasztalatszerzés hatása a gondolkodás fejlődésére}

Az ingergazdag környezetben a kisgyermek aktív, tevékeny életmódja következtében a megismerő folyamatok közül különösen a megfigyelés, a megjegyzés, a felismerés minden különösebb erőfeszítés nélkül olyan szintet ér el, hogy a kisgyermekkor végére a felmerülő problémahelyzeteket képes lesz a gyermek önállóan, cselekvésben gondolkodva megoldani. A tanulás olyan elemeit fejlesz- ti ki magában a gyermek, amely az egész életét alkotó módon végigkíséri. A matematikai nevelés szempontjából azért fontos mindez, mert a matematikai képességek a legkorábban megnyilvánuló képességek közé tartoznak, és kibontakozásukhoz az összes megismerő folyamatra, az érzékelésre - észlelésre - figyelemre - emlékezetre - képzeletre gondolkodásra szükség van. Ezért kell odafigyelni a matematikai nevelés kapcsán ezeknek a pszichikus folyamatoknak a fejlődésére, fejlesztésére.

A gondolkodás fejlesztése azért kap ilyen nagy hangsúlyt a kisgyermekkor matematikájában, mert szinte minden életkorban a matematikai nevelés-oktatás egyik legfontosabb célkitűzése. Öncélúak és formálisak lennének a matematikai ismeretek, ha nem kapcsolódnának összefüggésekké a gondolkodás segítségével. Ehhez azonban egyrészt a bátorító, inspiráló, az explorációt segítő személyi és tárgyi környezet megléte nélkülözhetetlen, másrészt a korai képességek feltérképezése kiemelt jelentőséggel bírhat a későbbi tanulási folyamatok eredményességének vonatkozásában.

Stella Lourenco, az amerikai Atlanta város Emory Egyetem Gyermektanulmányi Centrumának vezető pszichológusa szerint, ha a csecsemők térbeli gondolkozását és orientációját figyelemmel kísérjük, sok minden megtudható arról is, hogy a későbbiekben milyen matematikai képességeik lesznek. A tudományos kutatások szerint a térbeli gondolkodás jelei már hat hónapos korban megmutatkoznak, ami egyértelmüen összefüggésbe hozható a későbbi matematikai intelligenciával. Megállapították, hogy a térbeli gondolkodás képessége erősen összefügg a későbbi matematikai teljesítménnyel (Kissné és Farnady Landerl, 2018).

A tapasztalat az érzékelés, az észlelés, az emlékezés, a képzelet eredménye, anélkül, hogy a gondolkodást érintené. Érzékeléssel, észleléssel kezdődik a tapasztalatszerzés folyamata. A többször észlelt dolgokat már egy egyéves gyermek is képes felismerni. A felismerés az emlékezés első formája. Bonyolultabb szituációkban nehezebb a felis- 
merés, élményszerű szituációkban könnyebb az emlékezés. Emlékképeink nem mindig az észlelés valósághü reprodukciói, hanem bizonyos tulajdonságok hangsúlyosabban jelennek meg bennük, a lényeg dominálhat, általánosítással létrejöhet egy tipikus kép, amely a valóságot már mélyebben tükrözi, mint a közvetlen észlelés. Amikor az emlékezés már elszakad a valóságtól, akkor képzeleti képről, képzetek felidézéséről beszélünk. A matematikai tapasztalatszerzésnek is ez az útja (Cole és Cole, 2006).

Jean Piaget-nak köszönhető az a felismerés, hogy a gondolkodási struktúra kialakulása cselekvéssel kezdődik. Ezért beszélhetünk gondolkodási műveletekről már kora gyermekkorban. A legmagasabb szintü kognitívtevékenység a gondolkodás. Olyan problémák megoldásához szükséges, melyek közvetlenül észlelés, emlékezet, képzelet útján nem oldhatók meg. A problémahelyzet lényege, hogy van egy cél, amit szeretnénk elérni, de nem ismerjük a cél elérésének útját. Ezen kognitív funkciók által a tanulás olyan elemeit fejleszti ki magában a kisgyermek, amely az egész életét alkotó módon végigkíséri. A matematikai nevelés szempontjából azért fontos mindez, mert a matematikai képességek a legkorábban megnyilvánuló képességek közé tartoznak, és kibontakozásukhoz az összes megismerő folyamatra, az érzékelésre - észlelésre - figyelemre - emlékezetre - képzeletre és a gondolkodásra szükség van. Ezért kell odafigyelni a matematikai nevelés kapcsán ezeknek a pszichikus folyamatoknak a fejlődésére, fejlesztésére (Zsámboki, 2007).

A tapasztalatszerzés eredményeképp létrejövő gondolkodási és fogalomalkotási folyamatok fejlődésének áttekintése szintén fontos lehet, mert a nevelőmunka során - a személyiség harmonikus kibontakoztatása, az élmény- és tapasztalatszerzés mellett nagymértékben hozzájárulhatunk a gyermeki problémamegoldó gondolkodás fejlesztéséhez és a fogalmak alapozásához. (Matematikai és nem matematikai fogalmak alapozásához egyaránt.) A fogalomalkotás fejlődési fázisainak leírása Pólya György, világhírü magyar matematikus nevéhez kötődik.
A fejlődési fázisok kezdetén kiemelt jelentőséggel bír a tapasztalatszerzés, a tények és információk gyüjtése a tárgyakkal történő manipuláció közben. Ebben a fázisban fontos, hogy az adott fogalom lényegi vonásai ismétlődjenek, a nem lényegesek pedig változzanak. Sok-sok érzékszervi-mozgásos tapasztalatban, manipulációs lehetőségben legyen része a gyermekeknek az életkori sajátosságoknak megfelelő tárgyakkal, játékokkal. A második fázis során a tapasztalatok, az emlékképek „összeállnak”. A gyermekek ekkor már megfigyelik az adott fogalom tipikus jegyeit, és kialakult képzeteik alapján képesek az adott fogalomhoz hasonló formák felismerésére. A harmadik fázisban, a formalizálás során a képzetek gondolkodási műveletek (elsősorban elvonatkoztatás és általánosítás) során ismeretekké válnak. Megtörténik az ismeretek szavakba foglalása, azaz a fogalom megnevezése. Elvonatkoztatva minden más tulajdonságuktól, az eddig hasonlónak titulált formák most már ugyanazt az általános nevet kapják. Ez a szakasza későbbre, az óvodáskor végére, vagy a kisiskolás kor elejére tehető. A fogalomalkotás végső, asszimilációs szakaszában a fogalmak koherens rendszerbe illesztése történik, amelynek során bővül, esetleg strukturális változásokon is átmegy a rendszer. Maga a fogalom is változik, hiszen a gyermek számára világossá válik az adott fogalmi rendszerben elfoglalt helye és kapcsolata a más rendszerbéli elemekkel (Butterworth, 2005).

\section{A koragyermekkori számérzék és numerikus képességek vizsgálatai}

A tudományos kutatások eredményeképp ma már tudjuk, hogy biológiailag két elsődleges matematikai képességgel rendelkezünk. Az egyik a szubitizáció, azaz a kis mennyiségek (1-3) pontos meghatározásának és megkülönböztetésének képessége, a másik pedig a nagyobb mennyiségekre vonatkozó, megközelítő, kevésbé pontos összehasonlítási képesség. A biológiailag másodlagos matematikai képességek kialakulásához - mint 
például a matematikai érveléshez és a problémamegoldáshoz - elengedhetetlen a nyelv és a környezet, hiszen ezen közvetítők nélkül a gyermeki fejlődés nem tudna előrehaladni (Márkus, 2007).

A kisgyermekek számfogalmának alakulását célzott kutatási módszerekkel az 1980as évektől kezdték vizsgálni, amelynek egyik eszköze a habituáció módszere volt. Prentice Starkey és Robert G. Cooper (1980) kísérletében 4-7 hónapos csecsemőket vizsgáltak. A babák édesanyjuk ölében ültek és egy képernyőt figyeltek. A kutatók azt vizsgálták, hogy a csecsemők mennyi ideig nézték a vetített képeket, amelyeken eltérő távolságokban két fekete pontot ábrázoltak. Miután a gyermekek elvesztették érdeklődésüket a két pontot ábrázoló képek iránt, a képernyőn hirtelen három pont jelent meg. Ezt a képet a csecsemők szignifikánsan hosszabb ideig nézték, mint az előző, két pontot ábrázoló képeket. A három pontot tartalmazó képet tehát különbözőnek észlelték a két pontot tartalmazókhoz képest, amelyeket viszont egymással hasonlónak észleltek a csecsemők.

Mark S. Strauss és Lynne E. Curtis (1981) megismételte a fenti kísérletet, azonban pontok helyett hétköznapi tárgyakról készített fényképekkel végezték el, melyek több dimenzió mentén folyamatosan változtak, csupán a számosság maradt változatlan. A gyermekek ebben a helyzetben is kialakították a két tárgy számosságára vonatkozó képzetüket, és az érdeklődésük szintén felélénkült, amikor három különböző tárgy jelent meg a képernyőn (Dehaene, 2003).

Ranka Bijeljac-Babic, Josiane Bertoncini és Jacques Mehler (1993) pár napos csecsemőknek három szótagból álló, jelentés nélküli hangsorozatokat mutattak be. Miután a babáknak lecsökkent az érdeklődésük a 3 szótagú hangingerekre, két szótagú hangsorozatot adtak a kutatók, amire a babák újra hevesebben kezdtek reagálni (cumizni). A vizsgálati eredmények azt mutatták, hogy a kettő és három számérték reprezentációja tehát független az ingerbemutatás módjától, vizuális és hanginger esetén is megkülönböztetik azokat a csecsemők.
A fenti kísérletek eredményeinek érvényességét más kutatók az 1990-es évek végén kétségbe vonták, mert állításuk szerint szinte lehetetlen olyan ingereket tervezni, amikor csupán az elemek száma különbözik a két ábrán. Bizonyos perceptuális változók mindig együtt változnak a számossággal. Például amikor az elemek száma megváltozik, megváltozik az elemek együttes kerületének hoszsza, az általuk kitöltött terület vagy az általuk visszavert fény mennyisége is. Amennyiben a kutatók a babák számdiszkriminációs képességeire kíváncsiak, akkor biztosnak kell lenniük abban, hogy a csecsemők valóban a számosságra, és nem az azzal korreláló perceptuális változókra reagálnak (Clearfield $\mathcal{E}$ Mix, 1999). Az 1999 után végzett vizsgálatok nagyobb része számos módon próbálta ellenőrzés alatt tartani a perceptuális változók hatását, s a korábbiaknál jóval megbízhatóbb eredményeket produkáltak².

David C. Geary, neves amerikai kognitív fejlődés és evolúciós pszichológus 1995-ösv izsgálatai szerint legalább négy biológiailag öröklött numerikus képességgel rendelkezünk: a kis sokaság (3-4 elem) számosságának meghatározása, a számolás vagy becslés nélkül 5 alatti mennyiségeket tartalmazó halmazok összehasonlításának képessége, az elemszámlálási képesség, illetve az összeadás, kivonás 3-ig (Márkus, 2007). A számlálás mint szeriális képesség tehát öröklött. Ennek egyik jele az, hogy a gyermekek már kétéves koruk előtt számlálnak, még akkor is, ha nem megfelelő sorrendben. Hároméves kor körül megfigyelhető az aritmetikai képességek felgyorsulása, amelynek hátterében egyrészt az áll, hogy a gyermekek már megértik azt, hogy mindegyik szám neve egy meghatározott mennyiségnek felel meg. Másrészt pedig az, hogy képesek a rész-egész megkülönböztetésére. Több vizsgálat is rávilágít arra, hogy a gyermekek már öt éves kor előtt rendelkez-

\footnotetext{
2 A 21.századi újabb vizsgálatok egységesen arra mutattak rá, hogy a kisgyermekek akkor képesek két ponthalmaz számossága között különbséget tenni, ha a két halmaz elemeinek a száma legalább 1:2 arányban különbözik egymástól (Xu-Spelke, 2000).
} 
nek az összeadás és a kivonás koncepciójával is (Desoete $\mathcal{E}$ mtsai, 2009).

\section{Matematikai kompetenciák kisgyermekkorban}

A kompetencia alatt elsősorban olyan felkészültséget, gyakorlatban is alkalmazható tudást értünk, amely alkalmassá tesz arra, hogy különböző helyzetekben hatékonyan cselekedjünk. Olyan felkészültség, amely tudásra, készségekre, tapasztalatokra, értékekre, beállítódásokra épül. De vajon beszélhetünk-e már kisgyermekkorban matematikai kompetencia alapozásáról, fejlesztéséről?

A matematikai nevelés alapvető célja minden életkorban, hogy a gyermek személyisége és gondolkodása gazdagodjon, formálódjon. Az életkori sajátosságoknak megfelelően játékos tevékenységekkel, a fokozatosság elvének betartásával, a tapasztalatokon alapuló megismerési módszerek alkalmazásával lehet a matematikát, mint tudományágat közel hozni a világot a maga egységében és teljességében megélő gyermekekhez. Fel lehet fedeztetni a matematikát a gyermeket körülvevő természeti és társadalmi környezetben. Megfelelő módszerekkel már az óvodában el lehet kezdeni alakítani az önálló ismeretszerzés képességét, kiválóan lehet fejleszteni a problémafelismerő és problémamegoldó, alkotó gondolkodásmódot, előkészíteni, ala- pozni a szám- és műveletfogalmat, a számolási készséget. Hatékonyan lehet alapozni azon komplex szemléletmódot, amely szerint a matematika nem csupán önálló tudomány, hanem más tudományok segítője, a mindennapi életünk része, az emberiség kulturális örökségének része, gondolkodásmód, alkotó tevékenység, a gondolkodás örömének forrása, valamint a rend és esztétikum megjelenítője a struktúrákban, mintákban. A fenti gondolatok tükrében tehát bátran válaszolhatunk igennel arra a kérdésre, hogy beszélhetünk-e már az óvodában matematikai kompetenciák alapozásáról, fejlesztéséről.

A matematikai kompetencia három összetevői a matematikai ismeretek, a matematikaspecifikus készségek, képességek, valamint a matematikával kapcsolatos motívumok, attitűdök. Értelemszerűen a matematikai nevelésben ezen három összetevő jelentőségének aránya eltérő. Az elvont matematikai ismeretek, tudományos fogalmak elsajátítása, megtanítása ma már nem lehet célja a koragyermekkori nevelésnek, de nem vonható kétségbe, hogy a gyermeki tevékenységekben - túlnyomó részt inkább indirekt módon jelen vannak ilyen tartalmak is. (pl. a körröl szerzett ismeretek, a kör fogalma a körjátékok alkalmával). A matematikai kompetencia legfontosabb képesség-, és készségkomponenseit az alábbi táblázatban foglaljuk össze:

\begin{tabular}{|c|c|c|c|c|}
\hline Készségek & $\begin{array}{l}\text { Gondolkodási } \\
\text { képességek }\end{array}$ & $\begin{array}{l}\text { Kommunikációs } \\
\text { képességek }\end{array}$ & $\begin{array}{l}\text { Tudásszerző } \\
\text { képességek }\end{array}$ & $\begin{array}{c}\text { Tanulási } \\
\text { képességek }\end{array}$ \\
\hline $\begin{array}{l}\text { - számlálás } \\
\text { - számolás } \\
\text { - mennyiségi } \\
\text { következtetés } \\
\text { - becslés } \\
\text { - mérés } \\
\text { - mértékegységváltás } \\
\text { - szöveges feladat } \\
\text { megoldás }\end{array}$ & $\begin{array}{l}\text { - rendszerezés } \\
\text { - kombinativitás } \\
\text { - deduktív } \\
\text { következtetés } \\
\text { - induktív } \\
\text { következtetés } \\
\text { - valószínüségi } \\
\text { következtetés } \\
\text { - érvelés } \\
\text { - bizonyítás }\end{array}$ & $\begin{array}{l}\text { - reláció szókincs } \\
\text { - szövegértés } \\
\text { - szövegértelmezés } \\
\text { - térlátás, térbeli } \\
\text { viszonyok } \\
\text { - ábrázolás } \\
\text { - prezentáció }\end{array}$ & $\begin{array}{l}\text { - problémaérzé- } \\
\text { kenység (kérdések) } \\
\text { - problémareprezen- } \\
\text { táció } \\
\text { - eredetiség, } \\
\text { kreativitás } \\
\text { - problémamegoldás } \\
\text { - metakogníció }\end{array}$ & $\begin{array}{l}\text { - figyelem } \\
\text { - rész-egész észlelés } \\
\text { - emlékezet } \\
\text { - feladattartás } \\
\text { - feladatmegoldási } \\
\text { sebesség }\end{array}$ \\
\hline
\end{tabular}

1. táblázat: A matematikai kompetencia legfontosabb képesség- és készség komponensei 
A kisgyermekkori matematikai kompetenciákról alkotott nézetek változása

A matematikai kompetencián belül az egyik legjelentősebb a gondolkodási képesség, de ez egyszerre többfajta képességen keresztül is realizálódhat (pl. rendszerezés, kombinativitás, deduktív és induktív következtetés, érvelés), és ezeknek más területen is működő komponenseknek kell lennie. Tehát az óvodai foglalkozásokon fejlesztett gondolkodási képességnek az élet számos más területein is alkalmazható képességgé kell válnia.

A rendszerező képesség egyrészt a feladatban, a felvetett problémában megjelenő információk, adatok kigyűjtését, rendszerezését jelenti, másrészt a gyermek képességét arra, hogy az újonnan megszerzett ismeretet beillessze az addigi ismeretek rendszerébe. Az életkornak megfelelő nyelvi fejlettség, szövegértés, szövegértelmezés, és a relációszókincs jelentése nem szorul értelmezésre, kiemelendő viszont, hogy a megléte elengedhetetlenül szükséges a matematikai szövegekben rejlő összefüggések felismeréséhez, megértéséhez. A memória terjedelme, az asszociatív memória és az értelmes memória a matematika kompetencia fontos komponensei. Az, hogy a gyermek egy ismeretet már készség szintjén elsajátított-e, és pl. meg tud-e egy erre az ismeretre épülő feladatot fejben oldani, ennek során jut szerephez a memória terjedelme. Egy-egy műveletsor (képlet) megjegyzése (alkalmazások során) a gyermek asszociatív memóriájának milyenségére utaló. Az értelmes memória a megjegyzendő dolgok között fellelhető összefüggések megértésével segíthet a tanulásban. A koragyermekkori nevelésben a leghangsúlyosabb a harmadik komponens, azaz a matematikával kapcsolatos motívumok, attitűdök formálása, a külső világban rejtőzködő és felfedezhető matematikai tartalmak és tapasztalatok iránti kíváncsiság fenntartása, az érdeklődés, a belső motiváció táplálása, amelyhez az életkori sajátosságoknak megfelelő pedagógiai módszerekre, a pedagógus által kezdeményezett játékokravan szükség (Skemp, 2005).

\section{Záró gondolatok}

A matematikai nevelésnek óriási szerepe van a gondolati tevékenységeknek a gyakoroltatásában, a gondolkodás hajlékonyságának fokozásában, a konstruáló képesség, a kreativitás fejlesztésében. Dienes Zoltán, nemzetközi hírű, magyar matematikadidaktikus szerint (2014) a gyerekek a tanult matematikának legnagyobb részét elfelejtik, ezért sem lehet célunk csupán az ismeretek elsajátítása.Az érés, fejlődés természetes folyamatát nem siettetni, hanem gazdagítani kell. Hároméves korra az egészséges kisgyermek érzékelése és mozgása összerendezett, szenzomotoros képessége alkalmassá teszi őt arra, hogy bánni tudjon környezetével, kiismerje magát a saját életterében, felfedezze és megtapasztalja az őt körülvevő szűkebb és tágabb emberi, természeti és tárgyi környezet mennyiségi, formai és téri viszonyait. A család, a pedagógusok és a nevelési intézmények felelőssége, hogy a szerzett tapasztalatok és ismeretek rendszerezéséhez, bővítéséhez, a matematikai szemléletmód alapozásához, az értelmi képességek, a logikai és problémamegoldó gondolkodás fejlesztéséhez aktivitásra serkentő, játékra hívogató eszközöket és környezetet, lehetőségeket és a gyermeki szabad alkotást és önkifejezést támogató légkört biztosítson.Az élmények és a velük kapcsolatos pozitív érzelmek teszik majd felejthetetlenné a matematikai tapasztalatokat és egyben kompetenssé a gyermekeket.

\section{Felhasznált irodalom}

Bijeljac-Babic, R., Bertoncini, J. \& Mehler, J. (1993): How Do 4-Day-Old Infants Categorize Multisyllabic Utterances? Developmental Psychology, 29. 4. sz., 711-721. https://doi.org/10.1037/0012-1649.29.4.711

Butterworth, B (2005): The development of arithmetical abilities, Journal of Child Psychology and Psychiatry, 46. 1. sz., 3-18. https://doi.org/10.1111/j.1469-7610.2004.00374.x

Clearfield, M. W. \& Mix, K. S. (1999): Number Versus Contour Length in Infants' Discrimination of Small Visual Sets. Psychological Science, 10. 5. sz., 408-411.

https://doi.org/10.1111/1467-9280.00177 
Cole, M. és Cole, R. S. (2006): Fejlődéslélektan. Osiris Kiadó, Budapest.

Dehaene, S. (2003): A számérzék. Miként alkotja meg az elme a matematikát? Osiris Kiadó, Budapest.

Desoete, A., Ceulemans, A., Roeyers, H. \& Huylebroeck, A. (2009): Subitizing or counting as possible srceening variables for learning disabilities in mathematics education or learning? Educational Research Review, 4. 1. sz., 55-66.

https://doi.org/10.1016/j.edurev.2008.11.003

Dienes Zoltán Pál (2014): Játék az életem - Egy matematikus mágus visszaemlékezései. EDGE 2000 KFT, Budapest.

Fábián Mária, Lajos Józsefné, Olasz Tamásné és Vidákovich Tibor (2008): Matematikai kompetenciaterület. Szakmai koncepció. Educatio Kht., Budapest.

Keysers, C. \& Gazzola, V. (2014): Hebbian learning and predictive mirror neurons for actions, sensations and emotions https://doi.org/10.1098/rstb.2013.0175

URL: https://www.ncbi.nlm.nih.gov/pmc/ articles/PMC4006178/ [2018.06.27.]

Kissné Zsámboki Réka (2017): Mindenben matematika. RAABE Klett Oktatási Tanácsadó és Kiadó Kft., Budapest.

Kissné Zsámboki Réka és Farnady-Landerl Viktória (2018): Neuropedagógiai innovációs lehetőségek a neveléstudományi kutatásokbanaz EMOTIV EPOC+ mobil EEG készülék alkalmazásával. Képzés és Gyakorlat 16. 3. sz., 21-36. https://doi.org/10.17165/TP.2018.3.3
Márkus Attila (2007): Számok, számolás, számolászavarok. Pro Die Kiadó, Budapest.

Pléh Csaba (2010): A lélektan története. Osiris Kiadó, Budapest.

Schiller, P. (2010): Early brain development research review and update. Exchange, 2010. November/December.

URL: https://www.childcareexchange.com/ library/5019626.pdf [2018.07.01.]

Skemp, Richard R. (2005): A matematikatanulás pszichológiája. EDGE 2000 KFT, Budapest.

Starkey, P., és Cooper, R. G. (1980): Perception of Numbers by Human Infants. Science, 210, 1033-1035. https://doi.org/10.1126/science.7434014

Starkey, P., Spelke, E. S. \& Gelman, R. (1983): Detection of intermodal numerical correspondences by human infants. Science, 222, 179-181.

https://doi.org/10.1126/science.6623069

Stern, Daniel N. (2002): A csecsemő személyközi világa. Animula Kft. Kiadó, Budapest.

Strauss, M. S. \& Curtis, L. E. (1981): Infant perception of numerosity. Child Development, $52,1146-1152$. https://doi.org/10.2307/1129500

Xu, F. \& Spelke, E. S. (2000): Large number discrimination in 6-month-old infants. Cognition, 74. 1. sz., B1-B11. https://doi.org/10.1016/S0010-0277(99)00066-9

Zsámboki Károlyné (2007): Babamatematika. ReploLAN, Sopron..

\section{Changes of the opinions about early childhood maths competencies}

Nowadays the crucial role of infant and early childhood is undoubted not only impersonal development and growing early cognitive functions but in social learning, too. Infants and children are self-constructive individuals whose development requires special support and care on curiosity and interest byplay and activities - as it was previously stated in the 1970s by Tamás Varga, the renowned Hungarian researcher and representative of teaching mathematics. Within this self-construction learning process numeric skills, mathematical experiences and competencies also can be developed. The aim of this study is to emphasise the need and importance of early mathematical education reflecting on changing views on children's thinking, numeric skills, numerical discrimination and mathematical competences in early childhood.

Keywords: thinking and construct of concepts, sense of number in the early years, inherited numeric skills, mathematical competencies 